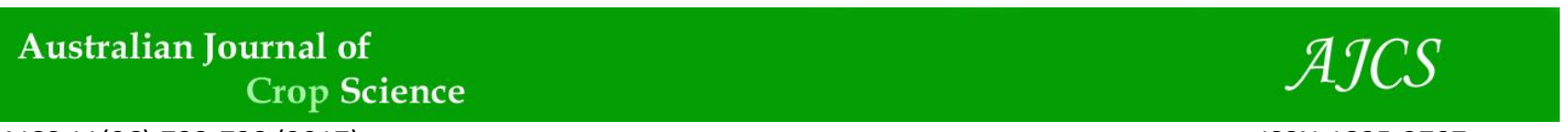

AJCS 11(06):733-738 (2017)

ISSN:1835-2707

doi: 10.21475/ajcs.17.11.06.p501

\title{
Effects of zeolite and organic fertilizers on soil quality and yield of sugarcane
}

\author{
Pedro Cairo Cairo ${ }^{1 *}$, Joaquin Machado de Armas $^{2}$, Pedro Torres Artiles ${ }^{2}$, Bladimir Diaz Martin ${ }^{1}$, \\ Rafael Jimenez Carrazana ${ }^{2}$ and Oralia Rodriguez Lopez $^{2}$
}

\author{
${ }^{1}$ Universidad de Atacama, Centro Regional de Investigación y Desarrollo Sustentable (CRIDESAT), Copiapó, \\ 1532000 Chile \\ ${ }^{2}$ Universidad Central de las Villas, Facultad de Ciencias Agropecuarias, Centro de Investigaciones \\ Agropecuarias, Santa Clara, 54830 Cuba
}

*Corresponding autor: pedro.cairo@uda.cl

\begin{abstract}
Maintaining or improving the soil quality is crucial for agricultural productivity. This study was undertaken to evaluate the effect of zeolite and its combination with chemical fertilizer and organic fertilizers on soil quality and sugarcane yield in the north coast of Cuba, Villa Clara province. The organic fertilizer (sugarcane filter cake-SFC), and natural mineral (zeolite-Z) and chemical fertilization (nitrogen-phosphorus-potassium-NPK) were applied as treatments. The experiment was laid out in a randomised complete block design with nine treatments and four replicates. The soil samples were taken at a depth of $0-20 \mathrm{~cm}$ to determine soil properties such as degree of soil aggregation, water-stable aggregates, permeability, lower plastic limit, $\mathrm{pH}$ in water, $\mathrm{pH}$ in $\mathrm{KCl}$, organic matter, assimilable $\mathrm{P}_{2} \mathrm{O}_{5}$ and $\mathrm{K}_{2} \mathrm{O}$. The sugarcane yield components such as cane yield $\left(\mathrm{t} \mathrm{ha}^{-1}\right)$ and sucrose yield ( $\mathrm{t}$ ha $\left.{ }^{-1}\right)$ were evaluated. Principal components analysis (PCA) and simple regression analysis were also performed. The best results on cane yield were obtained with the treatment Z $7.5 \mathrm{t} \mathrm{ha}^{-1}+$ SFC $22.5 \mathrm{t} \mathrm{ha}^{-1}$, which represent a relative increase of $200 \%$ vs control (without fertilization). Relations between soil properties and principal component analysis confirmed the good response of zeolite application on soil quality and sugarcane yield.
\end{abstract}

Keywords: Zeolite; organic fertilizer; sustainability; yield; Vertisol.

Abbreviations: OM_Organic matter; WSA_Water stable aggregates; DSA_Degree of soil aggregation; Z_Zeolite; SFC_Sugarcane filter cake; NPK_Nitrogen phosphorus potassium; SP_Soil permeability

\section{Introduction}

Soil is one of the most important environmental factors and is considered the main source in providing essential plant nutries, water reserves and a medium for plant growth (Ghaemi et al., 2014). Maintaining or improving soil quality is crucial for agricultural productivity and environmental safety which are to be preserved for future generations (Reeves, 1997; Lal, 2015). Because of its low cost and great versatility, zeolite also plays an important role in agriculture. Ghanbari and Ariafar, (2013) indicates that natural zeolite may represent an important alternative to reduce the effects of drought in arid and semi-arid regions. It can be used to improve the soils, boost the effects of chemical and organic fertilizers-alike, and as a component of substratum for the development of different crops (Najafi-Ghiri, 2014). In 2013, world production of natural zeolite was estimated to be 2.7 million to 3.2 million metric tons, with China accounting for more than 70 percent of production (Virta, 2013).

Zeolite is a naturally volcanogenic sedimentary mineral composed primarily of aluminosilicates (Pan et al., 1991). The mineral has a threedimensional crystal lattice, with loosely bound cations, capable of hydrating and dehydrating without altering the crystal structure (Ramesh and Damodar, 2011). About 40 natural zeolites and 100 synthetic zeolites exist (Szerment et al., 2014). In Cuba there are deposits of zeolites located in almost all provinces and geographical regions (Orozco y Rizo, 1998).

Mirzaei et al. (2015) showed the effects of application of nanozeolite and zeolite on MWDw as an index of aggregation stability and strength, and organic carbon aggregate size fractions in a soil treated with some plant residues during the incubation period. Aggregation process in the soil is important. It plays a considerable role in improving the soil physical characteristics such as hydraulic conductivity, infiltration, ventilation, etc. Also, the aggregation process is important in improving the carbon sequestration in soil (Lal, 2015). Zeolite assists water infiltration and retention in the soil due to its very porous properties and the capillary suction. Acting as a natural wetting agent, it is an excellent amendment for non-wetting sands and to assist water distribution through soils (Ghazavi, 2015; Szerment et al., 2014). Zeolite can hold nutrients in the root zone of plants until required. This leads to more efficient use of $\mathrm{N}$ and $\mathrm{K}$ fertilizers, using less fertilizer for the same yield or application of same amount of fertilizer for longer lasting and producing higher yields (Gamze, 2007; Khodaei-Joghan and Asilan, 2012).

The application of different soil treatments, which may include sources of organic matter and natural mineral such as zeolite, can alter the properties which manifest the biggest 
changes over time and are closely related with cane yield as soil quality indicators (Cairo et al., 2010). In the case of natural minerals, zeolites are crystalline microporous aluminosilicates which are built from corner-sharing $\mathrm{SiO}_{4^{-}}$ and $\mathrm{AlO}_{4}$-tetrahedra. These porous materials are formed in nature in association with volcanic activity (Weckhuysen and $\mathrm{Yu}, 2015)$. Sugarcane is widely cultivated in Vertisols of north coast of Villa Clara province, Cuba. Serious natural constraints are occurred for plant production in Vertisols due to undesirable physical properties such as extreme plasticity (Vidal et al., 2006). Limitations of Vertisols are impeded root development in the topsoil and decreased crop yields (Cairo et al., 2012). Because of their poor physical conditions, Vertisols are very susceptible to degradation under sugarcane monoculture, leading to extreme quality limitation (Cairo et al., 2012). The aim of this research was to evaluate the effect of the zeolite and its combination with fertilizer and organic fertilizers on soil quality and yield of sugarcane.

\section{Results and Discussion}

\section{Zeolite and organic fertilizer}

Different zeolite levels and combinations with organic fertilizers were applied in Vertisols (Table 1). Significant effects on organic matter and structure, as well as on sugarcane yield (cane yield and sucrose yield) were observed. Zeolite levels increased both soil properties and sugarcane yield, but combinations of zeolite with nitrogen or organic fertilizers achieved the best results. The sugarcane yield is closely related to the increase of organic matter and indicators of soil structure. Treatment, $\mathrm{Z} 7.5 \mathrm{t} \mathrm{ha}^{-1}+\mathrm{SFC}$ $22.5 \mathrm{t} \mathrm{ha}^{-1}$ (T6) showed the best result, where 3 of the indicators (organic matter, water-stable aggregates and degree of soil aggregation) reached the highest values of all treatments and sugarcane yield, with average assessment category, middle, excellent and good respectively. In this case the yield of sugarcane is almost doubled compared to the

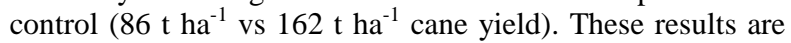
agreed with those obtained by Diaz et al. (2010) and Rodriguez et al., (2012). Leggo et al. (2000) and Najafi-Ghiri (2014) have demonstrated the effect of Zeolite combined with organic fertilizers on soil properties and yield of crops under extreme soil degradation conditions.

Fig. 1. shows the soil water regime by comparing the control treatment (T1) with the soil treated with $\mathrm{Z} 7.5 \mathrm{t} \mathrm{ha}^{-1}+\mathrm{SFC}$ $22.5 \mathrm{t} \mathrm{ha}^{-1}$ (T6), when sampling moisture is carried up from a meter deep after $25 \mathrm{~mm}$ of rainfall. In control treatment, water accumulated on the surface, remaining much drier in depth, due to the limited speed of water infiltration. However, treatment of soil with zeolite guarantees the uptake of rainwater in depth, due to the structural changes (Table 1), which is synonymous with a better use of rainwater and subsequent supply of assimilable water to plants. In the natural soils, all the detained superfluous water is lost by evaporation surface area which may be decisive in cane yield. The results show that the effect of the zeolite and its combination with organic fertilizer not only has its influence on the topsoil but also in depth. Xiubin and Zhanbin, (2001); Ozbahce et al., (2014); Ghazavi, (2015); Mirzaei et al., (2015) showed similar results highlighting the effects of zeolite on the aggregation and soil water retention. The dynamic characteristics of Vertisol under wet and dry conditions and the formation of deep cracks produced transfer of substrates from surface to depth which consequently caused a change in the structural diagram of the soil profile (Vidal et al., 2006; Cairo et al., 2012).

\section{Soil quality analysis}

In today's agricultural world much value has been given to organic matters and their relations with the structure and stability (Ghaemi et al., 2014), as these have direct influence on the quality of soil and its management under general degradation condition (Lal, 2015). Fig 2 and 3 show a close relationship and dependence ( $r>0.80$ ) between organic matter and water stable aggregation and soil permeability. The agroecological soil management alternatives determine the level of relations between organic matter and structural properties. These properties are sensitive to change by anthropogenic action but recovery may have residual effect over time as a result of the formation of organo-mineral complexes and in this case even more favored by the presence of the zeolite. Mirzaei et al. (2015) studied effects of natural zeolite and nano-zeolite on plant residues and obsereved significant results in the increment of organic carbon and soil aggregation. Lopes et al. (2016) reported close relations among organic matter with stable aggregates and the degree of soil aggregation that confirms the importance of these properties as indicators of the soil quality management.

Table 2 shows the trends of the properties studied when applying statistical tools and sensitivity to category change. Ghaemi et al. (2014) stated that the use of principal components can contribute to the assessment of soil quality and the sustainable management of an agricultural system. The properties that best demonstrate the qualities of indicators of soil quality are organic matter, stable aggregates, degree of soil aggregation, permeability log $10 \mathrm{~K}$ and lower plastic limit. In this case, they observed statistical significance of 60 and $90 \%$ with high sensitivity to change of category among the first component (Table 2). The maximum and minimum values of the properties and their evaluation are shown in Table 2. All other properties did not meet all of these requirements. On the other hand, it is very favorable that the cane yield shows similar results which can be considered as biological indicators of soil quality (Adeyolanu et al., 2013; D'Hose et al., 2014). Crop yield considered in these studies, had an extraordinary value for selecting quality indicators and determining soil quality. Hence, integration of natural minerals and organic amendments is suitable for Vertisols with high clay contents and improves physical soil properties. In similar studies, an improvement in the structural state of an inceptisol was observed with the application of organic and organic-mineral treatments, resulting in an increase of water-stable aggregates, degree of soil aggregation and permeability (Diaz et al., 2008, Mollinedo et al., 2015). There was also a proportional relationship between soil quality and sugarcane yield (Diaz et al., 2010; Kumar and Chand 2013; Jeevika et al., 2015).

A balanced use of organic, inorganic and biofertilizers is essential to maintain a good soil physical and chemical environment and also serves as an energy source for the soil microbial biomass (Rajesh et al., 2003; Gopalasundaram et al., 2012).

\section{Materials and Methods}

\section{Site description}

The study was plotted in the sugarcane growing areas of the northern coast of Villa Clara province (Fig. 4) in the municipality of Sagua La Grande, the Experimental Station of Sugarcane "Jesus Menendez" is localised at $22^{\circ} 81^{\prime} 19^{\prime \prime} \mathrm{N}$ 
Table 1. Influence of zeolite and sugarcane filter cake on organic matter, soil structure and sugarcane yield.

\begin{tabular}{|c|c|c|c|c|c|c|}
\hline Treatments & OM\% & WSA\% & DSA $\%$ & $\log 10 \mathrm{k}$ & $\begin{array}{c}\text { Cane yield } \\
\left(\mathrm{t} \mathrm{ha}^{-1}\right)\end{array}$ & $\begin{array}{l}\text { Sucrose yield } \\
\left(\mathrm{t} \mathrm{ha}^{-1}\right)\end{array}$ \\
\hline Control & $2.29 \mathrm{~g}$ & $64.18 \mathrm{e}$ & $54.03 \mathrm{e}$ & $1.84 \mathrm{f}$ & $86.37 \mathrm{i}$ & $14.99 \mathrm{i}$ \\
\hline $\mathrm{Z} 7.5 \mathrm{tha}^{-1}$ & $3.43 \mathrm{~cd}$ & $68.58 \mathrm{~d}$ & $57.24 \mathrm{~d}$ & $2.01 \mathrm{de}$ & $89.41 \mathrm{~h}$ & $15.31 \mathrm{~h}$ \\
\hline Z $15 \mathrm{t} \mathrm{ha}^{-1}$ & $3.57 \mathrm{~b}$ & $69.38 \mathrm{c}$ & $60.65 \mathrm{c}$ & $2.05 \mathrm{c}$ & $114.40 \mathrm{f}$ & $19.48 \mathrm{f}$ \\
\hline Z $7.5 \mathrm{t} \mathrm{ha}^{-1}+\mathrm{N}\left(100 \mathrm{~kg} \mathrm{ha}^{-1}\right)$ & $3.46 \mathrm{c}$ & $68.58 \mathrm{~d}$ & $57.24 \mathrm{~d}$ & $2.13 \mathrm{a}$ & $154.84 \mathrm{~b}$ & $26.14 \mathrm{a}$ \\
\hline Z $15 \mathrm{t} \mathrm{ha}^{-1}+\mathrm{N}\left(100 \mathrm{~kg} \mathrm{ha}^{-1}\right)$ & $3.52 \mathrm{~b}$ & $69.38 \mathrm{c}$ & $60.65 \mathrm{c}$ & $2.05 \mathrm{c}$ & $142.30 \mathrm{c}$ & $23.84 \mathrm{c}$ \\
\hline $\mathrm{Z} 7.5 \mathrm{t} \mathrm{ha}^{-1}+\operatorname{SFC}\left(22.5 \mathrm{tha}^{-1}\right)$ & $3.71 \mathrm{a}$ & $69.67 \mathrm{~b}$ & $65.57 \mathrm{a}$ & $2.09 \mathrm{~b}$ & $162.00 \mathrm{a}$ & $24.42 \mathrm{~b}$ \\
\hline Z $3 \mathrm{t} \mathrm{ha}^{-1}+\operatorname{SFC}\left(18 \mathrm{tha}^{-1}\right)$ & $3.40 \mathrm{de}$ & $71.04 \mathrm{a}$ & $62.62 \mathrm{~b}$ & $2.14 \mathrm{a}$ & $137.66 \mathrm{~d}$ & $22.95 \mathrm{~d}$ \\
\hline Z 7.5 t ha $^{-1}+\mathrm{NPK}\left(100-60-200 \mathrm{~kg} \mathrm{ha}^{-1}\right)$ & $3.37 \mathrm{e}$ & $68.58 \mathrm{~d}$ & $57.24 \mathrm{~d}$ & $2.00 \mathrm{e}$ & $135.79 \mathrm{e}$ & $22.19 \mathrm{e}$ \\
\hline Z $15 \mathrm{t} \mathrm{ha}^{-1}+\mathrm{NPK}\left(100-60-200 \mathrm{~kg} \mathrm{ha}^{-1}\right)$ & $3.24 \mathrm{f}$ & $69.38 \mathrm{c}$ & $60.65 \mathrm{c}$ & $2.04 \mathrm{~cd}$ & $106.93 \mathrm{~g}$ & $17.29 \mathrm{~g}$ \\
\hline $\mathbf{E E}= \pm$ & 0.06 & 0.27 & 0.49 & 0.01 & 3.90 & 0.58 \\
\hline
\end{tabular}

$(\mathrm{a}, \mathrm{b}, \mathrm{c}, \mathrm{d}, \mathrm{e}, \mathrm{f}, \mathrm{g})$ means with common letters do not differ in the same column by Tukey HSD at $\mathrm{p} \leq 0.05$. T Control without fertilization; Zeolite Z; N nitrogen; SFC (sugarcane filter cake); NPK (nitrogen-phosphorus-potassium); OM(Organic matter); WSA(Water stable aggregates); DSA (Degree of soil aggregation); Log 10k (Permeability)

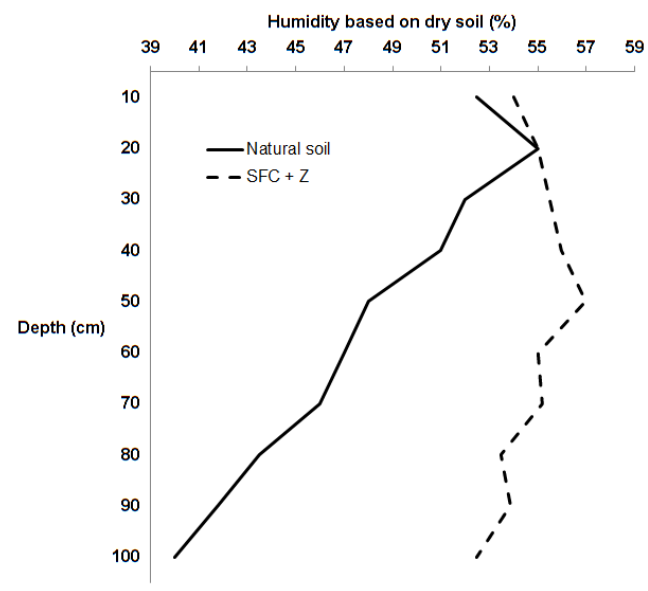

Fig 1. Soil moisture profile ( $25 \mathrm{~mm}$ of rain before sampling). ------ Average values of sampling of the soil moisture content (Z $7.5 \mathrm{t}$ $\mathrm{ha}^{-1}+\mathrm{SFC} 22.5 \mathrm{tha}^{-1}$ ___ Average values of sampling of the soil moisture content (Control without fertilization).

Table 2. Correlations, sensitivity to change of category and principal components.

\begin{tabular}{|c|c|c|c|c|}
\hline Properties & $\begin{array}{l}\text { Correlations (\%) } \\
\text { significant of } \\
\text { Total }\end{array}$ & \multicolumn{2}{|c|}{ Range (degree of sensitivity) } & $\begin{array}{l}\text { Principal } \\
\text { component }\end{array}$ \\
\hline $\begin{array}{l}\text { Water-stable aggregates } \\
(\%)\end{array}$ & 80 & $\begin{array}{l}64.00 \\
\text { Good }\end{array}$ & $\begin{array}{c}71.09 \\
\text { Excellent }\end{array}$ & 1 \\
\hline $\begin{array}{lcc}\begin{array}{l}\text { Degree } \\
\text { aggregation }(\%)\end{array} & \text { soil } \\
\end{array}$ & 80 & $\begin{array}{c}54.00 \\
\text { Bad }\end{array}$ & $\begin{array}{l}66.64 \\
\text { Good } \\
\end{array}$ & 1 \\
\hline Permeability (log 10K) & 80 & $\begin{array}{c}1.82 \\
\text { Adequate }\end{array}$ & $\begin{array}{c}2.50 \\
\text { Excellent } \\
\end{array}$ & 1 \\
\hline $\begin{array}{l}\text { Lower plastic limit } \\
(\% \text { Hbds })\end{array}$ & 90 & $\begin{array}{l}30.07 \\
\text { Plastic }\end{array}$ & $\begin{array}{c}42.67 \\
\text { Moderately plastic }\end{array}$ & 1 \\
\hline $\mathrm{pH}$ (in water) & 50 & $\begin{array}{c}5.69 \\
\text { Slightly } \\
\text { acid }\end{array}$ & $\begin{array}{c}6.45 \\
\text { Neutral }\end{array}$ & 1 \\
\hline $\mathrm{pH}$ (in $\mathrm{KCl})$ & 30 & $\begin{array}{c}5.10 \\
\text { Mildly acid }\end{array}$ & $\begin{array}{c}5.90 \\
\text { Slightly } \\
\text { acid }\end{array}$ & 2 \\
\hline Organic matter $(\%)$ & 60 & $\begin{array}{l}2,25 \\
\text { Low }\end{array}$ & $\begin{array}{c}3.75 \\
\text { Medium } \\
\end{array}$ & 1 \\
\hline $\mathrm{K}_{2} \mathrm{O}\left(\mathrm{mg} 100 \mathrm{~g}^{-1}\right)$ & 30 & $\begin{array}{c}10.48 \\
\text { Medium }\end{array}$ & $\begin{array}{l}17.67 \\
\text { High }\end{array}$ & 1 \\
\hline $\mathrm{P}_{2} \mathrm{O}_{5}\left(\mathrm{mg} 100 \mathrm{~g}^{-1}\right)$ & 40 & $\begin{array}{l}3.58 \\
\text { Low } \\
\end{array}$ & $\begin{array}{l}13.05 \\
\text { High }\end{array}$ & 1 \\
\hline Cane yield ( $\left.\mathrm{t} \mathrm{ha}^{-1}\right)$ & 60 & 86.30 & 162.15 & 1 \\
\hline Sucrose yield $\left(\mathrm{t} \mathrm{ha}^{-1}\right)$ & 70 & 14.98 & $\begin{array}{c}- \\
26.16 \\
\end{array}$ & 1 \\
\hline
\end{tabular}




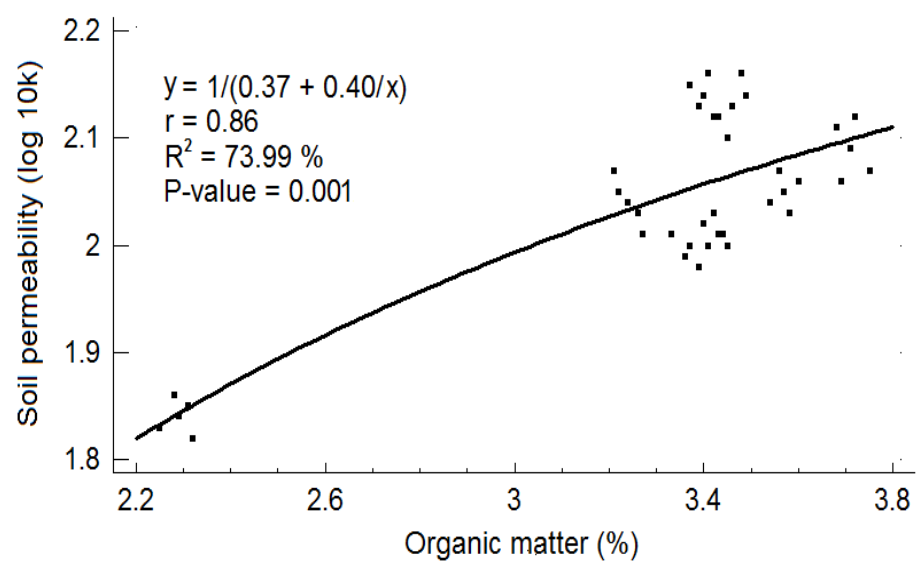

Fig 2. Relation between organic matter and soil permeability (simple regression equation, inverse double model, $\mathrm{p} \leq 0.05$ ).

Table 3. Chemical composition of the materials used in the experiment.

\begin{tabular}{llll}
\hline $\begin{array}{l}\text { Organic fertilizer } \\
\text { Parameter }\end{array}$ & Sugarcane filter cake & $\begin{array}{l}\text { Natural mineral } \\
\text { Parameter }\end{array}$ & Zeolite \\
\hline $\mathrm{N}(\%)$ & 2.85 & $\mathrm{SiO}_{2}$ & 63.00 \\
$\mathrm{P}(\%)$ & 1.71 & $\mathrm{Al}_{2} \mathrm{O}_{3}$ & 11.57 \\
$\mathrm{~K}(\%)$ & 0.91 & $\mathrm{~F}_{2} \mathrm{O}_{3}$ & 0.81 \\
$\mathrm{Ca}(\%)$ & 1.00 & $\mathrm{MgO}$ & 0.92 \\
$\mathrm{Mg}(\%)$ & 0.50 & $\mathrm{CaO}$ & - \\
$\mathrm{OM}(\%)$ & 43.00 & $\mathrm{TiO}_{2}$ & 0.45 \\
$\mathrm{C}(\%)$ & 24.94 & $\mathrm{Fe}_{2} \mathrm{O}_{3}$ & 1.87 \\
$\mathrm{C}: \mathrm{N}$ & 8.75 & $\mathrm{Na}_{2} \mathrm{O}$ & 2.39 \\
& & $\mathrm{P}_{2} \mathrm{O}_{5}$ & 0.09 \\
& & $\mathrm{Humidity}$ & 3.44 \\
\hline
\end{tabular}

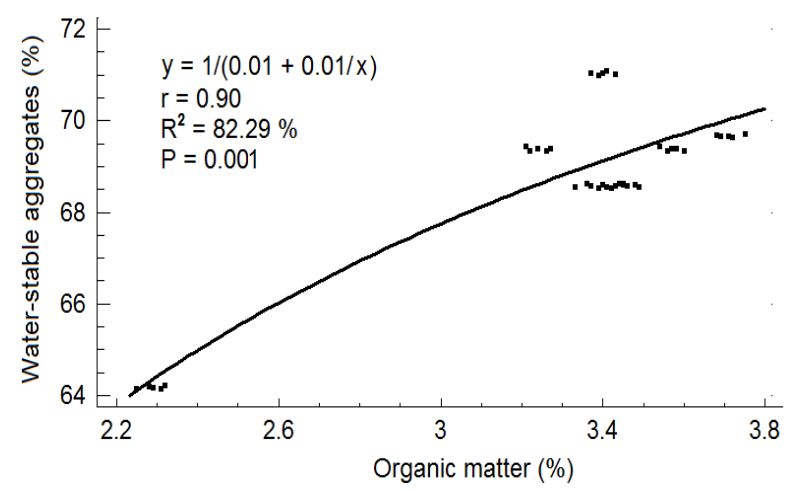

Fig 3. Relation between organic matter and water-stable aggregates (simple regression equation, inverse double model, $\mathrm{p} \leq 0.05$ ).

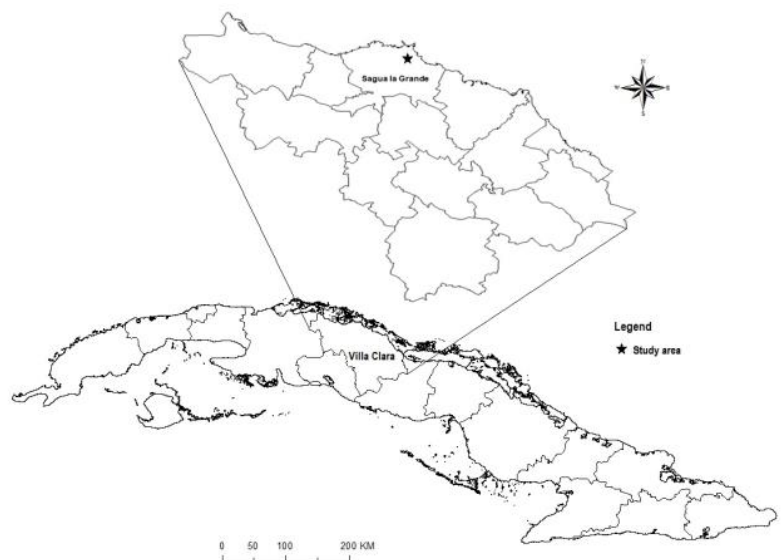

Fig 4. Map of Cuba with the study area in Villa Clara province. 
latitude and $80^{\circ} 03^{\prime \prime} 74^{\prime \prime} \mathrm{W}$ longitudes. The soil under study was Vertisols (Soil Survey Staff, 1999). Vertisols are very clayey, but plastic under intense water regime. The local climate is clasisified as Aw according to Köppen. Annual rainfall in the study area is $1150 \mathrm{~mm}$ and average temperature is $25^{\circ} \mathrm{C}$.

\section{Experimental design and treatments}

The Experiment was set up as a randomized complete block design with 9 treatments and 4 replications. The individual plot sizes were $10 \times 9.6 \mathrm{~m}$. Sugarcane variety Ja $60-5$ was used and was planted in furrows at $1.60 \mathrm{~m}$ row spacing. Organic fertilizer (sugarcane filter cake-SFC), and natural mineral (zeolite-Z) and chemical fertilization (nitrogenphosphorus-potassium-NPK) were applied.

The treatments were: T1- control (without application of fertilizer), T2- Z $7.5 \mathrm{t} \mathrm{ha}^{-1}$, T3- Z $15 \mathrm{t} \mathrm{ha}^{-1}$, T4- Z $7.5 \mathrm{t} \mathrm{ha}^{-1}+$ $\mathrm{N} 100 \mathrm{~kg} \mathrm{ha}^{-1}$, T5- Z $15 \mathrm{t} \mathrm{ha}^{-1}+\mathrm{N} 100 \mathrm{~kg} \mathrm{ha}^{-1}$, T6- Z $7.5 \mathrm{t} \mathrm{ha}^{-}$ ${ }^{1}+$ SFC $22.5 \mathrm{tha}^{-1,}$ T7- Z $3 \mathrm{t} \mathrm{ha}^{-1}+$ SFC $18 \mathrm{t} \mathrm{ha}^{-1}$, T8- Z $7.5 \mathrm{t}$ $\mathrm{ha}^{-1}+$ NPK (100-60-200 kg ha $\left.{ }^{-1}\right)$, T9- Z $7.5 \mathrm{t} \mathrm{ha}^{-1}+$ NPK (100-60-200 kg ha ${ }^{-1}$ ).

\section{Analysis of soil properties}

Soil sampling was performed 20 months after crop planting in each plot. Samples were taken from soil depth of 0 to 20 $\mathrm{cm}$. The chemical and physical properties were determined by the following methods: assimilable $\mathrm{P}_{2} \mathrm{O}$ and $\mathrm{K}_{2} \mathrm{O}$ by Oniani, (1964) with extractive solution of sulfuric acid $(0.1 \mathrm{~N})$. The $\mathrm{P}_{2} \mathrm{O}_{5}$ was colorimetrically determined and $\mathrm{K}_{2} \mathrm{O}$ by flame photometry. Organic matter was determined by the colorimetric method of Walkley and Black, (1934) and pH (in water and $\mathrm{KCl}$ ) by $\mathrm{pH}$-meter relation soil-water 1:2.5. Permeability (log 10k) was analysed according to Henin et al. (1958) and the degree of soil aggregationas described in Vageler and Alten, (1931). Water-stable aggregates were determined using the methodology by Henin et al. (1958) and the lower plastic limit by the Atterberg rolls method, Atterberg, (1911). Control treatments without fertilizer and Z $7.5 \mathrm{t} \mathrm{ha}^{-1}+$ SFC $22.5 \mathrm{t} \mathrm{ha}^{-1}$ sampling soil moisture was carried out to a depth of $1 \mathrm{~m}$ after a rainfall of $25 \mathrm{~mm}$.

\section{Soil quality assessment}

The selection of soil quality indicators has its theoretical basis in the investigations carried out by different authors such as Doran and Parkin, (1994); Karlen et al. (1997); Torstensson et al. (1998); Lal, (2015). Cairo et al. (2010) suggested a procedure that includes behavior of soil properties, sensitivity of properties to external changes, significance of properties in statistical processing, changes in property evaluation categories, and the quality indicators and their relationships to yield.

\section{Sugarcane yield and statistical analysis}

We also evaluated the total number of stems per plot and their weight in order to determine cane yield $\left(\mathrm{t} \mathrm{ha}^{-1}\right)$ and sucrose yield $\left(\mathrm{t} \mathrm{ha}^{-1}\right)$. For statistical processing, we used the package SPSS ver 13.0 and STATGRAPHICS 5.1 on Windows XP. Soil properties and yield were submitted to analysis of variance applying the F-test for significance and means compared by Tukey test $(\mathrm{p} \leq 0.05)$. Principal components analysis (PCA) and correlation matrix between the variables were applied in order to distinguish variables with a high percentage of correlation. Simple regression analysis was used to determine the degree of dependence between physical and chemical soil properties and properties related to crop yield.

\section{Conclusion}

It was found that the zeolite alone or combined with compost and mineral fertilizers produce significant effects on organic matter and soil structure and yields of sugarcane. The best results on yields of sugarcane were obtained with treatment $\mathrm{Z}$ $7.5 \mathrm{t} \mathrm{ha}^{-1}+$ SFC $22.5 \mathrm{t} \mathrm{ha}^{-1}$, which represents an increase of almost $200 \%$, compared to controls. The use of zeolite combined with organic fertilizer showed a better use of rainwater in the study conditions. Relations between soil properties and principal component analysis confirmed the responses to zeolite application on soil quality and yield of sugarcane.

\section{References}

Adeyolanu OD, Are KS, Oluwatosin GA, Ayoola OT, Adelana AO (2013) Evaluation of two methods of soil quality assessment as influenced by slash and burn in tropical rainforest ecology of Nigeria. Arch Agron Soil Sci. 59: $1725-1742$.

Atterberg A (1911) Die Plastizität der Tone. Internationale Mitteilungen für Bodenkunde. 1(1):10-43.

Cairo P, Dávila A, Colás A, Reyes A, Díaz B (2012) Alternative use of soil improvers, with emphasis on evaluation of organic matter and soil quality indicators. Ministry of Agriculture Cuba.Final Project Report. 102p.

Cairo P, Machado J, Reyes A, Díaz B (2010) Methodology for assessing and monitoring soil quality in the central region of Cuba. Centro de Investigaciones Agropecuarias, Facultad de Ciencias Agropecuarias, UCLV. Cuba. 17p.

D'Hose T, Cougnon M, De Vliegher A, Vandecasteele B, Viaene N, Cornelis W, Van Bockstaele E, Reheul D (2014) The positive relationship between soil quality and crop production: A case study on the effect of farm compost application. Appl Soil Ecol. 75:189-198.

Diaz B, Barreto B, Cairo P, Pineda E, Mas R, Acosta F, Becerra E, Clavelo B (2008) The application of organic fertilizers and natural minerals in the sugar cane crop (part I): effect on the physical properties of Inceptisol soil and the yield of sugar cane crop. Cent Azucar. 35:1-10.

Diaz B, Barreto, B, Cairo P, Pineda, E, Mas R, Acosta F, Becerra E, Clavelo B, Quiñones R (2010) The application of organic fertilizers and natural minerals in the sugar cane crop (part II): Long term effect on the yield of sugar cane crop and soil quality. Cent Azucar. 37: 35-42.

Doran JW, Parkin TB (1994) Defining and assessing soil quality. In: Doran JW, Oleman DC, Bezdicek DF, Stewart BA. (eds). Defining soil quality for a sustainable environment. Madison. Soil Sci Soc Am. p.107-124.

Gamze T N (2007) The effects of natural zeolite on salinity level of poultry litter compost. Biores Technol. 99: 20972101.

Ghaemi M, Astaraei AR, Emami H, Mahalati MN (2014) Determining soil indicators for soil sustainability assessment using principal component analysis of Astan Quds- east of Mashhad- Iran. J Soil Sci Plant Nutr. 14: 987-1004.

Ghanbari M, Ariafar S (2013) The effect of water deficit and zeolite application on Growth Traits and Oil Yield of Medicinal Peppermint (Mentha piperita L.) Int J Med Arom Plants. 3(1): 33-39. 15. 
Ghazavi R (2015) The application effects of natural zeolite on soil runoff, soil drainage and some chemical soil properties in arid land área. Int J Innov Appl Stud. 13(1):172-177.

Gopalasundaram P, Bhaskaran A, Rakkiyappan P (2012) Integrated nutrient management in sugarcane. Sugar Tech. 14(1): 3-20.

Henin S, Monnier G, Combeau A (1958) Méthode pour l'étude de la stabilité structurale des sols. Ann Agron. 9: 73-92.

Jeevika K, Saliha BB, Vijayakumar M (2015) Soil quality indicators based recommendation to maximize sugarcane productivity in Theni district of Tamil Nadu. India $\mathbf{J}$ Appl Nat Sci. 7: 215-218.

Karlen DL, Mausbach MJ, Doran JW, Cline RG, Harris RF, Schuman GE (1997). Soil Quality: A concept, definition, and framework for evaluation. Soil Sci Soc Am J. 61:4-10.

Khodaei-Joghan A, Asilan KS (2012) Zeolite influences on nitrate leaching, nitrogen-use efficiency, yield and yield components of canola in sandy soil. Arch Agron Soil Sci. 58: 1149-1169.

Kumar V, Chand M (2013) Effect of integrated nutrients management on cane yield, juice quality and soil fertility under sugarcane based cropping system. Sugar Tech. 15:214-218.

Lal R (2015) Restoring soil quality to mitigate soil degradation. Sustainability. 7: 5875-5895.

Leggo PJ (2000) An investigation of plant growth in an organo-zeolitic substrate and its ecological significance. Plant Soil. 219:135-146.

Lopes E, Cairo P, Colás A, Rodríguez A (2016) Relations between indicator quality properties, into two subtypes of brown soils in the province of Villa Clara. Cent Agríc. 43 (1): 21-28.

Mirzaei, M, Akbar A, Mohsen S (2015) Aggregation stability and organic carbon fraction in a soil amended with some plant residues, nanozeolite, and natural zeolite. Int J Recycl Org Waste Agricult. 4:11-22.

Mollinedo J, Schumacher TE, Chintala R (2015) Influence of feedstocks and pyrolysis on biochar's capacity to affect the soil water retention characteristics. J Anal Appl Pyrol. 114:100-108.

Najafi-Ghiri M (2014) Effects of zeolite and vermicompost applications on potassium release from calcareous soils. Soil \& Water Res. 9: 31-37.

Oniani OF (1964) Determination of soil phosphorus and potassium in the same solution of Krasnozem and podzolic soils in Georgia. Agrojima 6:25.
Orozco G, Rizo R (1998) Depositos de zeolitas naturales de Cuba. Acta Geol Hisp. 33 (1-4): 335-349.

Ozbahce A, Tari F, Gönülal E, Simsekli N, Padem H (2014) The effect of zeolite applications on yield components and nutrient uptake of common bean under water stress. Arch Agron Soil Sci. 61(5): 615-626.

Pan G, Tan S, Yu G, Yin S (1991) Some agricultural properties of natural zeolite. Jiangsu J Agricult Sci. 7:31-6. (inChinese)

Rajesh C, Reddy K S, Naidu MVS, Ramavataram N (2003) Production and evaluation of compost and vermicompost from solid organic wastes. Asian J of Microbiol Biotechnol Environ Sci. 5: 307-311.

Ramesh K, Damodar D (2011) Zeolites and their potential uses in agriculture. Advances in Agron.113:219-235.

Reeves D W (1997) The role of organic matter in maintaining soil quality in continuous cropping systems. Soil Till Res. 43:131-167.

Rodríguez A, Cairo P, Torres P, Dávila A, Rodríguez O, Carrazana R, Gattorno S (2012) Selection of hydromorphic soil quality indicators of Villa Clara province. Cent Agríc. 39(3):5-9.

Szerment J, Ambrozewich-Nita A, Kedziora K, Piasek J (2014) Use of zeolite in agriculture and environmental protection. A short review. UDC: 666.96:691.5.

Torstensson L, Pell M, Stenberg B (1998) Need of a strategy for evaluation of arable soil quality. J Ambio 37: 4 -8 .

Vageler VP, Alten F(1931) Böden des Nil und Gash IV. Z für Pflanzenernähr Düng Bodenk. 22(2): 191-267.

Vidal L, Cairo P, Menning P, Könker H, Alonso N, Gutierrez A (2006) Slot drainage of clay soils under sugarcane in Cuba. Irrig Drain. 55 (5): 511-521.

Virta R (2013) Zeolites advance release. USGS science for a chengig world. $4 \mathrm{p}$.

Walkley A, Black I A (1934) An examination of the Degtjareff method for determining soil organic matter, and a proposed modification of the chromic acid titration method. Soil Sci. 37(1):

29-38.

Weckhuysen M, Yu J (2015) Recent advances in zeolite chemistry and catalysis. Chem Soc Rev.44: 7022-7024.

Xiubin H, Zhanbin H (2001) Zeolite application for enhancing water infiltration and retention in loess soil. Res Conservation and Recycling, 34: 45-52. 